\title{
Older, online and first: Recommendations for retention and success
}

\author{
Cathy Stone \\ The University of Newcastle, Australia, and the National Centre for Student Equity in Higher Education
}

\section{Sarah O'Shea}

The University of Wollongong, Australia, and the National Centre for Student Equity in Higher Education

\begin{abstract}
The university student population in Australia contains increasing numbers of older students returning to learning after a significant gap in their educational journey. Many are choosing to enrol online to combine their studies with other time-consuming responsibilities. This article examines the nature of this online student experience with a focus on those aged 25 and over who are the first in their families to embark on university studies. Drawing on interviews conducted with both staff and students operating in this virtual space, as well as other related research and literature, this article offers recommendations to higher education institutions and educators on ways to improve retention and ongoing participation of this cohort.
\end{abstract}

\section{Introduction}

Increasing numbers of Australian students are choosing to enrol as external students, in which the mode of education delivery is primarily online. Statistics from the Australian Government Department of Education and Training (2017b) show that the percentage of commencing domestic students in Australian higher education (HE) enrolling in a fully external mode grew from $17.5 \%$ in 2010 to $21.9 \%$ in 2015. Figures for the full year of 2016 indicate further growth, with $22.8 \%(93,905)$ of the 411,228 commencing students enrolling as fully online students. Available data indicate that mature-age and firstin-family students are generally more strongly represented in online than face-to-face studies (Open Universities Australia, 2015; The Open University, n.d.), as well as students from the Australian Government-identified equity categories of low socio-economic status (SES) backgrounds; regional and remote areas; students with disability; and Aboriginal and Torres Strait Islander (Indigenous) students (Stone, 2017).

The benefits of attending university include those related to social, economic and health outcomes (Cassells, Duncan, Abello, D’Souza, \& Nepal, 2012; Laming, Martin-Lynch, \& Morris, 2016; Marmot, 2004). For students entering university not as school leavers, but later in life, the rationale for returning is complex but it is often the pragmatic and economic reasons that are regarded as being key influencing factors (Laming et al., 2016). However, many of these older students are also coming from backgrounds where no one in their family, nor perhaps their friendship groups and communities, has been to university before, hence they are facing significant additional challenges (O'Shea, 2016; O'Shea, Stone, \& Delahunty, 2015; Stone \& O’Shea, 2012).

The term first-in-family or first generation has gained traction in the Australian university sector since 2015, with a number of studies focusing explicitly on this group (Bell et al., 2015; King, Luzeckyj, McCann, \& Graham, 2015; O’Shea, May, Stone, \& Delahunty, 2017). With the increasing numbers of first-in-family students attending university this focus is perhaps not surprising (Organisation for Economic Co-operation and Development [OECD], 2013; Spiegler \& Bednarek, 2013). The percentage of first-in-family at university within Australia is estimated to exceed $50 \%$ of the total student population (Spiegler \& Bednarek, 2013). This is a global phenomenon with the mean OECD average across member countries hovering around 53\% (OECD, 2013). Although being first does not necessarily equate to educational disadvantage, a number of studies have pointed to the differences in the motivations and experiences of this cohort (Ball, Davies, David, \& Reay, 2002; King et al., 2015; O’Shea et al., 2017). However, most studies focus on the undergraduate on-campus student population with less attention being paid to the online student experience, particularly of those mature-age students who are returning to education after a significant break in learning, usually with additional demands in their personal lives. 
The term mature-age varies in definition across institutions and countries. This article focuses on those first-in-family students who are aged 25 or over, recognising that this age group is more likely to be financially independent from parents or caregivers, more likely to be in the paid workforce and/or to have responsibility for others, such as partners and children. This is supported by the Australian Bureau of Statistics' $(2010,2016)$ consistent use of the age category of 15-24 to define and measure young people's engagement with both education and the workforce and its use of 25 and over to measure the engagement of older learners and employees. Within this paper the term first-in-family refers to those students who are the first in their immediate family, including siblings, partners, parents and children, to participate in university, while the term online learners refers to those students enrolled in HE in a distance or external mode, with learning content delivered online. As such, many may not be required to attend any face-toface learning experiences throughout their entire degree program, while some may be required to attend occasional sessions on campus, or professional placements in a workplace. Many may also be required to be physically present to sit examinations. However, for the most part, these students are studying away from campus, at their computer or other digital device, not physically attending classes.

This paper focuses on the experience of first-in-family students aged 25 and over who are undertaking their university studies as online learners. In bringing together the findings and recommendations from two pieces of research, this paper attempts to improve understanding of this student cohort, including ways in which these learners can be better supported to succeed in their studies.

\section{Literature review}

There is literature and scholarship that explores the experiences of older learners, online students and those who are first-in-family, but much of this tends to look at each category separately, rather than in combination. Many online learners are both mature-age and first in their family to come to university (Stone, O’Shea, May, Delahunty, \& Partington, 2016), so conflating these characteristics can provide a richer understanding of this particular student cohort experience. The following literature review highlights the issues associated with studying online as well as being older and first-in-family.

\section{Exploring the online learning experience}

Research has revealed many challenges associated with online learning. These particularly include technology challenges, which can be overwhelming for "novice adult learners” (Yoo \& Huang, 2013, p. 160), course material and delivery not appropriately designed for online delivery (Devlin \& McKay, 2016), along with inadequate interaction with teachers and other students (Ilgaz \& Gülbahar, 2015). Evidence points to the importance of "instructor immediacy in motivating participation" (Kuyini, 2011, p. 11) and "relationship-building strategies" in online teaching to reduce students" "feelings of aloneness and isolation" (Resop Reilly, Gallagher-Lepak, \& Killion, 2012, p. 104). Despite the increased focus on online delivery since the mid 2000s, recent research has shown that, amongst many academic and professional staff involved in online education at Australian universities, there is a perception that their universities view online delivery "as being less important, or of a lower priority, than on-campus education delivery” with an "'out of sight, out of mind' phenomenon” operating to the detriment of high quality online education delivery (Stone, 2017, p. 26).

Statistics indicate that attrition is considerably higher amongst external, online students than those studying face-to-face on campus. Retention in online study has been shown to be at least $20 \%$ lower than in face-to-face programs (Greenland \& Moore, 2014; Stone et al., 2016), with evidence for degree completion rates being even lower (Department of Education and Training, 2017a), while a recent Australian "Higher Education Standards Panel Discussion Paper" (Department of Education and Training, 2017c) indicates that external students are 2.5 times more likely than on-campus students to withdraw without a qualification.

There is debate over the extent to which these higher attrition rates can be attributed to the more diverse nature of the online student cohort or to the challenges inherent in the mode of delivery. Certainly, the higher proportions of older learners means that many within the online cohort are time-poor, juggling multiple responsibilities in their lives, such as family and work commitments, along with their studies (Greenland \& Moore, 2014; Müller, 2008; Park \& Choi, 2009; Tyler-Smith, 2006). This can be particularly problematic for women facing the gendered nature of expectations around family 
responsibilities and domestic work (Burke \& Crozier, 2014; Pocock, Skinner, \& Ichii, 2009; Stone \& O'Shea, 2013). Women are "much more likely [than men] to feel rushed and pressed for time" (Pocock et al., 2009, p. 2) and to have their time for study "dictated by the need to ensure that it [does] not impinge on family time” (Stone \& O'Shea, 2013, p. 103).

Overall, what the literature and research tell us is that the diversity and circumstances of the online cohort needs to be considered when universities offer online programs. The next section considers the learning contexts of those who are also older and first-in-family.

\section{Older, online and first in the family - what are the issues?}

Older online learners who are also first-in-family are likely to be entering university with an "initial lack of knowledge about university, combined with uncertainty about their abilities” (Stone et al., 2016, p. 162); they are also less likely to be able to look to family for support in relation to their studies as "sharing information or having full conversations about their experiences of university is often limited by the family's lack of experience and knowledge” (Stone et al., 2016, p. 163). Often, older learners are framed in terms of deficit, or within a "narrative of disadvantage" (Woodfield, 2011, p. 410), which is itself open to challenge (O’Shea, 2018). Indeed, there are risks in returning to education after a significant gap in learning, which include "rupture" with existing relationships, a need to manage "competing demands" and work with "identity formation” (O’Shea, 2015, p. 246). However, for many older learners, the decision to enrol in university can be rooted in previous negative educational experiences or a desire to fulfill a long-term ambition or dream (Stone \& O’Shea, 2012). These emotional connotations can act as powerful influences as Waller, Bovill, and Pitt (2011, p. 522) so eloquently describe:

The power of education and achievement in our society is such that falling short and appearing 'uneducated' can provoke 'shame' and humiliation. Such feelings compel some to return later to prove to themselves and others that that they are not 'uneducated' or 'stupid'.

The first-in-family student also faces challenges. They are reported as being both less likely to attend university and to have a higher risk of attrition (Australian Bureau of Statistics, 2013; Harrell \& Forney, 2003; Lehmann, 2009; Snyder \& Dillow, 2013). Across OECD member countries it is estimated that those students who have a family tradition of HE participation are almost twice (1.9 times) as likely to attend university than their first-generation peers (OECD, 2013, p. 3). There are many reasons identified for this, not least of which is a level of academic under-preparedness, which can engender feelings of dislocation and culture shock in this environment (Pascarella, Pierson, Wolniak, \& Terenzini, 2004). For those who are choosing online studies, the particularities of the issues encountered are little appreciated.

The following sections will discuss two recent qualitative Australian studies (O'Shea, May, \& Stone, 2015; Stone, 2017), one of which has examined ways to improve the online student experience while the other has included a focus on the online experience within a broader study of the first-in-family student experience (Stone et al., 2016). The aim of bringing these studies together is to shed a clearer light on older, first-in-family learners, studying online and to offer recommendations for HE institutions on ways to improve the retention and ongoing participation of these learners.

\section{Research design}

As mentioned, the data discussed in this article are derived from two separate but complementary studies.

\section{Study One - exploring ways for institutions to improve student outcomes in online learning}

In Study One (Stone, 2017), 151 members of staff were interviewed during 2016, across 16 HE institutions; 15 were Australian metropolitan and regional universities, while the sixteenth was the Open University UK. The study sought the combined wisdom of practitioners directly involved in online education, on ways to most effectively engage, teach and support online students. From the findings, a set of national guidelines for improving student outcomes in online learning has been developed (Stone, 2017). 
Interviews were conducted face-to-face and occasionally by phone, with the consent of each of the universities. Academic and professional staff nominated by their universities as being involved in online education were invited to participate, and a snowballing approach was then used, with staff being asked to distribute the invitation to others; 70 were in academic and teaching roles, 75 in professional roles and six were at senior executive levels. Professional roles included library services, learning design, student support, retention, engagement and success, language and learning, equity and diversity, disability services, careers, training and development, planning and data analytics. Teaching staff were drawn from different disciplines, schools and faculties across each institution.

\section{Study Two - First-in-family learners and HE participation}

In Study Two, O’Shea, May et al. (2015) undertook in-depth interviews and surveys between 2014 and 2015 across a number of HE providers with students who were first in their families to come to university. Interviews were semi-structured and followed a narrative biographical approach, with the main theme exploring how these participants transitioned into, and engaged with, the university environment. A total of 274 students participated across the whole study, with 101 interviewees and 173 survey respondents; of these, 88 were studying online as external students and 74 of these were aged 25 and over. This article refers specifically to these 74 online learners who participated in an interview ( $n=$ 38 ) or a survey $(n=36)$. Amongst this group more than two-thirds were women with child dependants and more than two-thirds were also in paid work.

Both studies received relevant ethics approvals. In Study One, interviews with staff focused on discussion of strategies they or others in their institution were using to engage and support online students, the impact of these on student retention and academic success and their views on what else institutions need to do, to better engage, support and retain online students. In Study Two, the student participants were recruited by email and they chose whether to be interviewed by phone or to complete an online survey. As in Study One, the interviews and surveys were qualitative in nature, with the interviews being semistructured. Questions explored why respondents had decided to enrol in university, the types of reactions this decision had engendered and how individuals managed the complexities of their life and study as online students.

Both studies adopted an iterative approach to data analysis, which involves a repetitive, cyclical approach of continually dipping between the interview and survey data. As themes begin to emerge they are checked against the data, which in turn helps each emerging theme to develop further while new themes emerge, and so on. Iteration has been described as "a deeply reflexive process... [which] is at the heart of visiting and revisiting the data and connecting them with emerging insights, progressively leading to refined focus and understandings” (Srivastava \& Hopwood, 2009, p. 77). Themes were then coded using NVivo. Combining Study One's focus on the perspectives of staff involved in developing, delivering education and/or providing support to students within online education, with Study Two's focus on the personal experiences of being an online student, provides a richly descriptive view of this field. The following section summarises the findings that both studies had in common.

\section{Findings}

A number of similarities and consistencies emerged from the findings of the two studies in relation to factors influencing the retention and persistence of online students. These are summarised below as four key findings.

\section{Understanding and valuing the nature of the online student cohort}

Emerging from both studies was the importance of institutions having an understanding of the nature of the online undergraduate student cohort; particularly acknowledging that this is a valuable cohort containing high numbers of first-in-family older students with other pressing responsibilities in their lives, as illustrated by quotes such as, "Due to the odd hours I work, travelling to and from a university is difficult” (Female survey respondent, Study Two); and "It gives you that flexibility to say I can take on a fair bit of full time work" (Male interviewee, Study Two). 
Fitting studying in around other responsibilities was particularly problematic for the female students, most of whom were parents. Study had to be accommodated around domestic and caring responsibilities, leaving very limited time for engaging in their learning:

While the children are not here, that's when I study and everything else has to be done. The children cope better with me doing housework and jobs and other things while they're around; they don't cope with me saying, "I need you to be quiet. I'm thinking”. (Mother of three, Study Two)

Many older students are choosing online study as the only possible option, as their other family and work commitments preclude on-campus attendance, yet interviews with staff in Study One revealed that many perceived that online education was treated by their institutions as "secondary education" rather than "core business” (Online Program Coordinator, Study One). “[Online] students have always been treated as kind of like the poor cousin and you don't worry too much about them ... it's really hard to get them to be taken seriously” (Unit Coordinator, Study One).

As other research with online students has suggested, "more work needs to be done to avoid online learners identifying themselves as 'second-class citizens' or 'just an online student'” (O'Shea, Stone, et al., 2015). Despite their "invisibility" on campus these students want and need to feel that they are included in and belong to the institution as equal members of the student community. They value highly any efforts by staff to reach out to them, to communicate with them and to encourage interaction and collaboration; hence the significance of the next finding.

\section{Communication and personal contact}

The isolation experienced by online students, particularly those who are first-in-family, can inhibit them from reaching out for help and support, or simply asking a question. Study Two found that "being offered and receiving institutional help and support was highly valued” (Stone et al., 2016, p. 160) by this student cohort, as shown by comments such as: “the fact that when I get in touch with these people they don't tell me just to go and look at a document; they actually help me and that makes a big difference" (Female interviewee, Study Two); and "It's nice to hear another human being's voice, just to let you know how you're going” (Female interviewee, Study Two).

Consistent with these findings, staff interviewed for Study One talked about the importance of early contact between the student and the institution, so that, "students actually understand what they're taking on, making appropriate choices ... and having an early contact with a human being at the university" (Student Services Manager, Study One). Encouraging new online students to engage in orientation activities through a range of media including online, telephone or even face-to-face contact was viewed as important. "They get a personal invite with their name, to come to a face-to-face event, they come on campus ... to connect with each other, to connect with staff and to get some skills” (Equity Officer, Study One.)

There were also examples of taking orientation off-campus to online students in other locations. "We literally jump in the cars and we go and visit students around the orientation period twice a year. We have regular catch-ups with students from there so we try to make a face-to-face connection for those online students" (Student Engagement Director, Study One). Such outreach work can also help to involve families and communities, which, as shown in Study Two, are important sources of support and motivation for first-in-family students, despite having a limited understanding of what is involved in undertaking further studies (O’Shea et al., 2017).

Communication also needs to be personalised and situated rather than general, as one senior manager in Study One explained: "We don't send a 'Dear student' email; we send a 'Dear Jason' email. We work very hard to know who you are, where you are in your journey, what part of the process you're in.” Undoubtedly, when online students regularly receive messages that are not relevant for them, it suggests to them that the university does not know who they are, nor perhaps does it care. As O'Shea, Stone et al. (2015) reported, when students received generic emails it conveyed "a lack of institutional awareness of, or interest in, their particular needs and requirements” (p. 55). 


\section{Designing and delivering for online}

An online course needs to be considered as "a different animal to the face-to-face course", designed "completely differently for that mode of delivery" (Academic, Study One). This is supported in research with mature-age online students by O’Shea, Stone et al. (2015) in which students expressed surprise "that some online courses consisted of face-to-face material put up online with little regard for the very different teaching medium” (p. 52). In the words of one of the students interviewed for this research, "What works in person in not the same as online ... I thought it would be more, sort of, more tailor made for it than what it is” (O’Shea, Stone et al., 2015, p. 52). Various researchers (Devlin, 2013; Mayes, Ku, Akarasriworn, Luebeck \& Korkmaz, 2011; Parsell, 2014) report that practices such as recording face-toface lectures and uploading them for online students, rather than providing specifically designed online content, provides a disengaging experience. This is consistent with the experience of participants in Study One, illustrated by the comment that "If we're going to move more online, you don't just tape yourself for an hour and put it on there; that's terrible” (Director of Teaching and Learning, Study One).

Online education is contributing to the "changing role of educators" (Devlin \& McKay, 2016, p. 101) where "in the use of technology in teaching, there is less emphasis on the notion of the educator as sage on the stage and more interest in the idea of him/her as a guide on the side” (Devlin \& McKay, 2016, p. 101). One of the key findings of Study One was the importance of the guiding influence of the online teacher, with "teacher-presence" (Stone, 2017, p. 17) emerging as crucial in effective online teaching. "The engagement demands are completely different, the reliance of students on the instructor is much more intensive - basically you're it. The instructor is everything to the students" (Course Coordinator, Study One).

Again, this is supported by the experience of mature-age online students who referred to "“don't bother" me' tutors” and 'disappearing lecturer'” (O’Shea, Stone et. al, 2015, p. 49). Evidence indicates that effective online delivery encourages “interactive and connected learning” (Devlin \& McKay, 2016, p. 99) and that the online teacher has a "fundamental role of interaction in bringing an online learning community into existence and for building and maintaining interpersonal relationships” (Delahunty, Verenikina, \& Jones, 2014, p. 253).

Evidence from Study One indicates that teacher engagement and connection with the online students has a demonstrable positive effect on retention figures. "They [tutors] are very consistent communicating every day, every week and ... this particular unit has a retention rate well into the 90\%" (Faculty Dean, Study One). Similarly, Study Two revealed the extent of appreciation from students when staff engaged with them at a personal level rather than as a faceless or unknown statistic. One of the female interviewees explained that if she had not received the genuine and helpful verbal support from her lecturer after her partner became unwell, "I would have dropped out because things were just so helterskelter here.” It needs to be recognised, however, that effective online teaching is a time-consuming process. Within the findings from Study One, the following point is made: "Valuing the importance of teacher-presence and the dedication of online teachers needs to extend beyond rhetoric and be incorporated into formal institutional expectations and guidelines, accompanied by a realistic workload model” (Stone, 2017, p. 38).

Effective online design also needs to take into account the difficulties with technology that online students can experience, particularly those new to online study (Yoo \& Huang, 2013). One of the participants in Study Two, for example, found that her level of technical understanding did not always go far enough:

There was a section that couldn't be any more than 10 megabytes and it was lucky I knew what that was but mine was 44 megabytes. I had no idea how to reduce it. And when you're living in isolation it's very difficult. (Female interviewee)

This is supported by other research with online students:

It was my very first experience of studying online, and having that Blackboard, and looking at your screen, going, "What the ...?”, and, “Where do I go?”, and "What do I do?”. I've used computers at work ... used different things over the years and different programs ... 
but ... just the whole, “Oh God ... this is really quite different”. (O'Shea, Stone et al., 2015, p. 52)

Hence the learning platforms on which online content is delivered need to be designed to be "as simple as possible ... without making technology another hurdle that they have to get over" (Senior Lecturer, Study One). "I think for online students more than anything, it's just got to work. It can't take time; it's got to be easily navigated, it's got to talk to me quickly and it's just got to be accessible” (Student Support Project Coordinator, Study One). Hurdles such as these can be enough to discourage students from continuing unless they receive timely support and assistance, as outlined in the next finding.

\section{Timely, proactive, embedded support}

Analysis of the data from both studies revealed the need to provide older, first-in-family students with support that is "targeted, promoted, appropriate and easily available to the many students who may lack the time, the confidence and the sense of entitlement to ask for support” (O’Shea et al., 2017, p. 210). For online students, such support includes not only the types of communication and contact previously discussed, but also support that is "embedded within the curriculum as much as possible, hence delivering it where and when it is most needed" (Stone, 2017, p. 10). This includes academic skills, technology support and personal support services. Providing easy links to timely, relevant support, within their learning content is an important way to point students in the right direction for the appropriate help they may need, at the right time, or as described by a participant in Study One: "Putting the material in that is relevant for the student at that point in time so that they hopefully don't have to go searching all around the universe and get lost” (Online Curriculum Manager).

Designing content to include support, so that, "rather than it's over here, outside of the discipline base, it's actually embedded” (Teaching \& Learning Senior Manager, Study One) ensures that required skills training is "integrated within the classroom task, and usually within the assessment task" (Language \& Learning Support Manager, Study One). Study Two found that first-in-family online students "particularly value support that reaches out to them, rather than expecting them to find it by themselves" (Stone et al., 2016, p. 162). Amongst this cohort there is often a deep sense of "'gratitude' for being 'allowed' to be at university" (O'Shea et al., 2017, p. 210), which can serve to "inhibit students from being too demanding of support and assistance” (Stone et al., 2016, p. 163). The quote below illustrates the importance of proactive support that reaches out to these students:

I got an email ... just checking in with everyone and telling me that they were here to help. Uni is hard so give us a call if you ever want a chat ... then a couple of days later I thought I'm going to call these guys. It was really helpful. I had a chat to a woman over the phone who was really great. She just had a chat to me about all of my options and about exploring what I could do. (Female interviewee, Study Two)

The four key findings discussed above emerged from examining the commonalities in findings between Study One and Study Two. In the following section, recommendations from these findings are discussed.

\section{Discussion}

This section explores the implications of the above findings and makes recommendations for practitioners and institutions involved in online education on ways to assist this older, first-in-family cohort to stay and succeed in online learning. This discussion is organised under the following themes:

- Recognising the students' limited access to a significant other

- Acknowledging the prior experiences of this cohort and the strengths they bring with them to their studies

- Creating a sense of belonging for online learners

- Developing conversations and interactions to enhance learning and knowledge sharing Limited access to a significant other

Online learners are, by nature, both spatially and temporally isolated. As first-in-family learners, their isolation is further compounded by the lack of access to a significant other within the household or the 
community who can provide ready assistance. Quality online provision needs to create an engaged community and provide opportunity for interactivity and communication between student and institution, as well as between students, to reduce the barrier of physical isolation.

Learners who may already feel out of place at university and then lack access to regular reassurance or advice about university, face invisible and significant disadvantages. This can impact on the development of a student identity where, similar to the older students in Blair, Cline, and Wallis' (2010) study, these learners may not consider themselves as 'real' students but rather as "individuals on the threshold of studenthood” (p. 142). This can be exacerbated by limited access to what Ball and Vincent (1998) refer to as “'hot' knowledge” (p. 377), social networks that can provide insights into the workings of the institution. While "hot" knowledge sources are not as reliable as the "cold" knowledge derived from formal institutional contexts, they are regarded as being more accessible to learners. Without access to these hot sources of information, there is an increased reliance on the learner to seek out necessary support and information by themselves.

Appreciating such contexts is vital for those involved in delivering online education. Ensuring that students feel connected with and supported by the institution from the very beginning, through regular personal and relevant interactions, is of key importance. Evidence from Study One indicates that this is most effective as an institutional framework of interventions, rather than relying on proactive individual members of staff to take the initiative. International examples include the MILLS Framework at the Open University UK (Slade \& Prinsloo, 2015) and New Zealand research by Nichols (2010) showing that when ad hoc academic support was replaced with a more formalised academic support process in which "a series of strategic interventions" (p. 94) were implemented, “first-time student course completion rose by 24.7 points across a single semester” (p.107).

Student mentoring or buddy programs are another important source of support. One participant in Study Two explained how the buddy system encouraged by her online teacher gave her access to a more experienced external student from whom she could seek clarification around issues that she did not understand. In many ways, this provides the opportunity for the dissemination of hot knowledge amongst this online community.

Examples from Study One of strategies to encourage student-to-student support included "the employment of more senior students who are trained to assist new students” (Stone, 2017, p. 44) as well as volunteer peer mentor programs such as:

Online students assisting other students, whether it be some assistance with "I'm new to online study. How do I go about this?” Or, if they're struggling in a particular area, keeping up with course work and balancing work and study, things like that, just providing that support to other students and helping them through. (Careers Service Manager, Study One)

\section{Acknowledging their prior experiences and strengths}

For older learners, the decision to attend university is often more than the desire to increase skills or learning but may be the realisation of a long-term ambition or goal. Amongst the online learners in Study Two "for many, it was a long-held dream that they would one day go to university and get a degree" (Stone et al., 2016, p. 154). Such motivations can engender a strong sense of purpose or even higher levels of persistence amongst this older cohort (O'Shea, 2018). Their maturity and experiences means that they bring a range of skills and strengths with them to their studies, which are often insufficiently recognised and capitalised upon by their enrolling universities. As Study Two found, "FiF students come with capacities and capabilities that can be harnessed for success” (O'Shea et al. 2017, p. 204), while in Study One "participants stressed the importance of not taking a deficit view of the students but instead recognising their considerable strengths in terms of experience, commitment and resilience” (Stone, 2017, p. 28). Similarly, Cox and Ebbers (2010) reported how older learners are a unique cohort that "bring with them different and multiple experiences, roles and responsibilities than those of traditional age students ... experience different transitions ... and have a different focus” (p. 241).

In previous research, O'Shea (2016) reflected upon how institutions often fail to recognise the skills and knowledges that learners, particularly older participants, may arrive with at the institution. Drawing upon 
older student narratives, O’Shea (2016, p. 46) points to a form of “experiential capital” or "knowledge sets that had been derived from life and professional experiences. Such experiences provided unexpected support and insider knowledges that learners indicated were having positive contribution to their academic success”.

Amongst the mature-age, first-in-family online cohort, there is a great deal of practical experience and wisdom which these students bring with them into the classroom setting. Through designing learning content that is relevant to their lives as working, responsible adults with extensive life experience, these students are more likely to feel included, and to value their experience and what it can offer to the learning process. One example of this is learning design that "links university study to the workplace more effectively” (Downing, 2015, p. vi), which in turn can engender greater support from the workplace, which is known to be positively correlated with online student persistence (Park \& Choi, 2009). Many of the online teaching staff in Study One talked of ways in which, through their teaching, they aimed to encourage students "to appreciate and draw upon their past and current life and work experience to aid them in their studies, rather than discounting it” (Stone, 2017, p. 29). Similarly, Signor and Moore (2014) reflect upon the ways in which diversity "can enrich online programs when mature age students are encouraged to utilise and share their knowledge and experiences with peers and educators” (p. 312).

\section{Creating a sense of belonging for online learners}

Previous research (Quinn, 2005; Read, Archer, \& Leathwood, 2003) has indicated how students from diverse backgrounds may have little sense of belonging within the university environment. Mature-age learners may be "disadvantaged by an identity that is marginalised and detached from student networks or sociality and information” (Mallman \& Lee, 2014, p. 4). For those older online students who lack the opportunity to socialise with their peers in learning, this sense of being different or not belonging may be further exacerbated. For example, a male participant in O’Shea, Stone et al.'s (2015) study of mature-age online students, described feeling as if he is "second fiddle" (p. 51) as an online student. Older students have reported that the opportunity to meet and converse with other older students provides a much needed validation of their decision to attend university (Stone \& O’Shea, 2012).

As discussed in finding 3, institutions need to consider ways of creating a sense of community for online learners. Study One's findings stress the importance of "regular and structured contact between the institution and the student” (Stone, 2017, p. 5), beginning with prospective online student advice, through to online orientation programs, and then continuing at key points, including times when the student may be identified as being at-risk academically. Establishing a strong sense of connection between student and teacher is of particular importance. As was found in Study One, "A strong teacher-presence provides online students with a sense of belonging, helping them to feel connected to a community of learning and increasing their likelihood of persisting” (Stone, 2017, p. 5). The role of the educator in building a sense of belonging amongst their students is manifestly important. Providing timely reassurance in the form of constructive feedback, positive reinforcement and opportunities for meaningful interaction with other students are all particularly important for those learners who are first in their families to come to university.

As discussed below, the lack of knowledge or understanding about university from others in their homes and communities may result at best in only minimal or constrained conversations about their studies. Feeling a sense of 'belonging' to their class and institution is therefore even more important.

\section{Conversations to enhance learning and knowledge sharing}

For a student who is first in the family to attend university, the opportunity to have meaningful conversations about their learning may be limited (O'Shea, 2014; O'Shea et al., 2017). Participants in Study Two revealed that talking about their university experiences with those closest to them could be difficult, and in some cases, somewhat threatening to the household. For example, one of the participants reported that her family's view of her decision to go to university was, "Why?... when you already have a good paying job, and haven't you left it a bit late? And why spend all that money? You'd be better off putting it into your mortgage” (O’Shea et al., 2017, p. 127). This lack of opportunity to engage in oral reflection with others can represent a significant but somewhat invisible barrier or limitation in their studies. Many of the online teaching staff interviewed in Study One referred to the importance of 
generating peer interaction through collaborative learning tasks and encouraging students to share information about themselves, including aspects of their life experience. Approaches to this included practices such as reflection and journaling, encouraging learners to engage in self-directed learning. Equally, creating contexts where there is opportunity for discussion via both synchronous and asynchronous methods or including assignments that engage learners in genuine dialogue with their fellow learners or colleagues in their professional or personal lives can lessen the isolation of online study.

\section{Conclusion}

Studying online as an external student presents a different set of challenges from those involved in studying face-to-face on campus, while being an older student who is also first-in-family to come to university presents further challenges. Within online undergraduate study, high numbers of older, first-infamily students are represented. Findings from the two studies discussed in this article indicate that there are a number of strategies that HE educators and institutions can employ to improve the retention and persistence of the older, first-in-family cohort, studying online. Recognising, understanding and valuing this cohort for the strengths and experience that it brings to university, is one important part of the picture. Creating a positive and engaging learning experience that includes integrated and embedded support, through the design and delivery of online undergraduate programs, can add another important element. If HE institutions can bring together an understanding and appreciation of both the needs and contributions of this cohort, with appropriate educational design, delivery and support, it is likely that many more firstin-family, older students will be able to stay, persist and succeed as online students.

\section{Acknowledgments}

The authors would like to acknowledge the National Centre for Student Equity in Higher Education for its encouragement and support of this article.

\section{References}

Australian Bureau of Statistics. (2010). Are young people earning or learning? Canberra: Author. Retrieved from http://www.ausstats.abs.gov.au/ausstats/subscriber.nsf/LookupAttach/4102.0Publication16.03.105/\$Fi le/41020_LearningorEarning.pdf

Australian Bureau of Statistics. (2013). Hitting the books: Characteristics of higher education students. Canberra: Author. Retrieved from http://www.abs.gov.au/AUSSTATS/abs@.nsf/Lookup/4102.0Main+Features20July+2013

Australian Bureau of Statistics (2016). Education and Work, Australia, May 2016. Retrieved from http://www.abs.gov.au/AUSSTATS/abs@.nsf/Lookup/6227.0Main+Features1May 2016?OpenDocument

Ball, S. J., Davies, J., David, M., \& Reay, D. (2002). 'Classification’ and 'Judgement': Social class and the 'cognitive structures’ of choice of higher education. British Journal of Sociology of Education, 23(1), 51-72. https://doi.org/10.1080/01425690120102854

Ball, S. J., \& Vincent, C. (1998). I heard it on the grapevine': 'Hot' knowledge and school choice. British Journal of Sociology of Education, 19(3), 377-400. https://doi.org/10.1080/0142569980190307

Bell, A., Airini, Benton M., Kelly-Laubscher, R., Paxton, M., Pukepuke, T., Santamaria, L., \& Wolfgramm-Foliaki, E. (2015). Australia, New Zealand, South Africa and Canada: Convergences and divergences in the experiences of first-generation university students. In Program and Book of Abstracts of Leading Learning and the Scholarship of Change. Twelfth Annual Conference of the International Society for the Scholarship of Teaching \& Learning (p. 189). Melbourne: International Society for the Scholarship of Teaching \& Learning. Retrieved from http://www.issotl.com/issotl15/sites/default/files/ISSOTL 2015 Program Book WEB.PDF

Blair, E., Cline, T., \& Wallis, J. (2010). When do adults entering higher education begin to identify themselves as students? The threshold-of-induction model. Studies in Continuing Education, 32(2), 133-146. https://doi.org/10.1080/0158037X.2010.488355

Burke, P. J., \& Crozier, G. (2014). Higher education pedagogies: Gendered formations, mis/recognition and emotion. Journal of Research in Gender Studies, 4(2), 52-67. Retrieved from 
https://www.addletonacademicpublishers.com/260-journal-of-research-in-gender-studies/volume-4-22014/2337-higher-education-pedagogies-gendered-formations-mis-recognition-and-emotion

Cassells, R., Duncan, A., Abello, A., D’Souza, G., \& Nepal, B. (2012). Smart Australians: Education and innovation in Australia (AMP NATSEM Income and Wealth Report, Issue 32). Canberra: University of Canberra, NATSEM. Retrieved from

http://www.natsem.canberra.edu.au/publications/?publication=ampnatsem-income-and-wealth-reportissue-32-smart-australians-education-and-innovation-in-australia

Cox, E. M., \& Ebbers, L. H. (2010). Exploring the persistence of adult women at a midwest community college. Community College Journal of Research and Practice, 34(4), 337-359. https://doi.org/10.1080/10668920802545088

Delahunty, J., Verenikina, I., \& Jones, P. (2014). Socio-emotional connections: Identity, belonging and learning in online interactions. A literature review. Technology, Pedagogy and Education, 23, 243265. https://doi.org/10.1080/1475939X.2013.813405

Department of Education and Training. (2017a). Completion rates of higher education students: Cohort analysis, 2005-2014. Canberra: Australian Government. Retrieved from

https://docs.education.gov.au/documents/completion-rates-higher-education-students-cohort-analysis2005-2014

Department of Education and Training. (2017b). Higher education statistics - Student data. Canberra: Australian Government. Retrieved from https://www.education.gov.au/student-data

Department of Education and Training. (2017c). Improving retention, completion and success in higher education (Higher Education Standards Discussion Paper, June 2017). Canberra: Australian Government. Retrieved from https://docs.education.gov.au/node/44121

Devlin, M. (2013). eLearning vision. Ballarat: Federation University. Retrieved from http://federation.edu.au/_data/assets/pdf_file/0020/159122/FedUni_eVision2014.pdf

Devlin, M., \& McKay, J. (2016). Teaching students using technology: Facilitating success for students from low socioeconomic status backgrounds in Australian universities. Australasian Journal of Educational Technology, 32(1), 92-106. https://doi.org/10.14742/ajet.2053

Downing, J. (2015). Applied learning design in an online teacher-education course (Doctoral dissertation). Retrieved from http://researchrepository.murdoch.edu.au/id/eprint/30925/

Greenland, S. J., \& Moore, C. (2014). Patterns of student enrolment and attrition in Australian open access online education: A preliminary case study. Open Praxis, 6(1), 45-54. https://doi.org/10.5944/openpraxis.6.1.95

Harrell, P. E., \& Forney, W. S. (2003). Ready or not, here we come: Retaining Hispanic and first generation students in postsecondary education. Community College Journal of Research and Practice, 27(2), 147-156. https://doi.org/10.1080/713838112

Ilgaz, H., \& Gülbahar, Y. (2015). A snapshot of online learners: E-readiness, e-satisfaction and expectations. International Review of Research in Open and Distributed Learning, 16(2), 171-187. Retrieved from http://www.irrodl.org/index.php/irrodl/article/view/2117/3277

King, S., Luzeckyj, A., McCann, B., \& Graham, C. (2015). Exploring the experience of being first in family at university: A 2014 Student Equity in Higher Education Research Grants Project. Perth: Curtin University, National Centre for Student Equity in Higher Education. Retrieved from https://www.ncsehe.edu.au/publications/exploring-the-experience-of-being-first-in-family-atuniversity/

Kuyini, A. B. (2011). Exploring the effects of including students' ideas and concerns on their participation in online groups. International Journal of E-Learning \& Distance Education, 25(3), 114. Retrieved from http://www.ijede.ca/index.php/jde/article/view/732/1292

Laming, M., Martin-Lynch, P., \& Morris, A. (2016). Mature-age men's experiences of higher education: Australia and England compared: A literature review. London: Society of Research into Higher Education.

Lehmann, W. (2009). University as vocational education: Working class students' expectations for university. British Journal of Sociology of Education, 30(2), 137-149. https://doi.org/10.1080/01425690802700164

Mallman, M., \& Lee, H. (2014). Stigmatised learners: mature-age students negotiating university culture. British Journal of Sociology in Education, 37(5), 684-701. https://doi.org/10.1080/01425692.2014.973017

Marmot, M. (2004). Status syndrome: how our position on the social gradient affect longevity and health. London: Bloomsbury. 
Mayes, R., Ku, H., Akarasriworn, C., Luebeck, J. \& Korkmaz, O., (2011). Themes and strategies for transformative online instruction: A review of literature and practice. Quarterly Review of Distance Education, 12(3), 151-166. Retrieved from http://www.infoagepub.com/qrdeissue.html?i=p54c3c57a10889

Müller, T. (2008). Persistence of women in online degree-completion programs. International Review of Research in Open and Distributed Learning, 9(2), 1-18. Retrieved from http://www.irrodl.org/index.php/irrodl/article/view/455/1042

Nichols, M. (2010). Student perceptions of support services and the influence of targeted interventions on retention in distance education. Distance Education, 31(1), 93-113. https://doi.org/10.1080/01587911003725048

Open Universities Australia. (2015, June). Online universities helping students become the first in their family to obtain higher education (Media Release).

The Open University. (n.d.). Facts and figures 2014/15. Retrieved from http://www.open.ac.uk/about/main/sites/www.open.ac.uk.about.main/files/files/fact_figures_1415_uk. pdf

Organisation for Economic Co-operation and Development. (2013). How are university students changing? Education Indicators in Focus - 2013/06 (September). Retrieved from https://www.oecd.org/education/skills-beyond-school/EDIF 2013--N¹5.pdf

O'Shea, S. (2014). Filling up silences: First in family students, capital and university talk in the home. International Journal of Lifelong Education, 34(2), 139-155. https://doi.org/10.1080/02601370.2014.980342

O’Shea, S. (2015). “I generally say I am a Mum first... but I’m studying at uni”: The narratives of first in family, female caregivers moving into an Australian university. Journal of Diversity in Higher Education, 8(4), 243-257. https://doi.org/10.1037/a0038996

O’Shea, S. (2016). Navigating the knowledge sets of older learners: Exploring the capitals of first-infamily mature age students. Widening Participation and Lifelong Learning, 18(3), 34-54. https://doi.org/10.5456/WPLL.18.3.34

O'Shea, S. (2018). Considering the cultural strengths of older first generation university students. In A. Bell \& L. J. Santamaria (Eds.), Understanding experiences of first generation university students: Culturally responsive and sustaining methodologies. London: Bloomsbury Publishing.

O’Shea, S., May, J., \& Stone, C (2015). Breaking the barriers: Supporting and engaging mature age first-in-family university learners and their families (Final Report). Canberra: Australian Government Office for Learning and Teaching. Retrieved from http://firstinfamily.com.au/report.php

O’Shea, S., May, J., Stone, C., \& Delahunty, J. (2017). First-in-family students, university experience and family life: Motivations, transitions and participation. London: Palgrave Macmillan.

O’Shea, S., Stone, C., \& Delahunty, J. (2015). “I 'feel' like I am at university even though I am online.” Exploring how students narrate their engagement with higher education institutions in an online learning environment. Distance Education, 36(1), 41-59. https://doi.org/10.1080/01587919.2015.1019970

Park, J. H., \& Choi, H. J. (2009). Factors influencing adult learners' decision to drop out or persist in online learning. Educational Technology and Society, 12(4), 207-217. Retrieved from http://www.ifets.info/journals/12 4/18.pdf

Parsell, M. (2014). Standards for online education (Final Report). Canberra: Australian Government Office for Learning and Teaching. Retrieved from https://www.onlinestandards.net/

Pascarella, E., Pierson, C., Wolniak, G., \& Terenzini, P. (2004). First-generation college students: Additional evidence on college experiences and outcomes. The Journal of Higher Education, 75(3), 249-284. https://doi.org/10.1353/jhe.2004.0016

Pocock, B., Skinner, N., \& Ichii, R. (2009). Work, life and workplace flexibility. Adelaide: University of South Australia. Retrieved from http://w3.unisa.edu.au/hawkeinstitute/cwl/documents/AWALI-09full.pdf

Quinn, J. (2005). Belonging in a learning community: The re-imagined university and imagine social capital. Studies in the Education of Adults, 37(1), 4-17. https://doi.org/10.1080/02660830.2005.11661504

Read, B., Archer, L., \& Leathwood, C. (2003). Challenging cultures? Student conceptions of 'belonging' and 'isolation' at a post-1992 university. Studies in Higher Education, 28(3), 261-277. https://doi.org/10.1080/03075070309290 
Resop Reilly, J., Gallagher-Lepak, S., \& Killion, C. (2012). “Me and my computer”: Emotional factors in online learning. Nursing Education Perspectives, 33(2), 100-105. Retrieved from https://www.ncbi.nlm.nih.gov/pubmed/22616408

Signor, L., \& Moore, C. (2014). Open access in higher education: Strategies for engaging diverse student cohorts. Open Praxis, 6(3), 305-313. https://doi.org/10.5944/openpraxis.6.3.132

Slade, S., \& Prinsloo, P. (2015). Stemming the flow: Improving retention for distance learning students. In A. Moreira Teixeira, A. Szücs, \& I. Mázár (Eds.), Expanding Learning Scenarios: Opening out the Educational Landscape. EDEN 2015 Annual Conference Proceedings. European Distance and ELearning Network. Retrieved from http://oro.open.ac.uk/44537/

Snyder, T. D., \& Dillow, S. A. (2013). Digest of education statistics 2012 (NCES 2014-015). Washington, DC: U.S. Department of Education. Retrieved from https://nces.ed.gov/pubs2014/2014015.pdf

Spiegler, T., \& Bednarek, A. (2013). First-generation students: what we ask, what we know and what it means: an international review of the state of research. International Studies in Sociology of Education, 23(4), 318-337. https://doi.org/10.1080/09620214.2013.815441

Srivastava, P., \& Hopwood, N. (2009). A practical iterative framework for qualitative data analysis. International Journal of Qualitative Methods, 8(1), 76-84. https://doi.org/10.1177/160940690900800107

Stone, C. (2017). Opportunity through online learning: Improving student access, participation and success in higher education (NCSEHE 2016 Equity Fellowship Final Report). Perth: Curtin University, National Centre for Higher Education. Retrieved from https://www.ncsehe.edu.au/publications/opportunity-online-learning-improving-student-accessparticipation-success-higher-education/

Stone, C., \& O’Shea, S. (2012). Transformations and self-discovery: Women returning to study. Champaign, IL: Common Ground Publishing.

Stone, C., \& O’Shea, S. (2013). Time, money, leisure and guilt: The gendered challenges of higher education for mature-age students. Australian Journal of Adult Learning, 53(1), 95-116. Retrieved from https://www.ajal.net.au/time-money-leisure-and-guilt-the-gendered-challenges-of-highereducation-for-mature-age-students/

Stone, C., O'Shea, S., May, J., Delahunty, J., \& Partington, Z. (2016). Opportunity through online learning: Experiences of first-in-family students in online open-entry higher education. Australian Journal of Adult Learning, 56(2), 146-169. Retrieved from https://www.ajal.net.au/opportunitythrough-online-learning-experiences-of-first-in-family-students-in-online-open-entry-highereducation/

Tyler-Smith, K. (2006). Early attrition amongst first time eLearners: A review of factors that contribute to drop-out. Withdrawal and non-completion rates of adult learners undertaking eLearning programmes. MERLOT Journal of Online Learning and Teaching, 2(2), 73-85. Retrieved from http://jolt.merlot.org/Vol2_No2.htm

Yoo, S. J., \& Huang, W. D. (2013). Engaging online adult learners in higher education: Motivational factors impacted by gender, age, and prior experiences. The Journal of Continuing Higher Education, 61(3), 151-164. https://doi.org/10.1080/07377363.2013.836823

Waller, R., Bovill, H., \& Pitt, B. (2011). Parents, partners and peers: Bearing the hidden costs of lifelong learning. International Journal of lifelong Education, 30(4), 509-526. https://doi.org/10.1080/02601370.2011.588464

Woodfield, (2011). Age and first destination employment from UK universities: Are mature students disadvantaged? Studies in Higher Education, 36(4), 409-425. https://doi.org/10.1080/03075071003642431

Corresponding author: Cathy Stone, cathy.stone@newcastle.edu.au

Australasian Journal of Educational Technology (c) 2019.

Please cite as: Stone, C., \& O’Shea, S. (2019). Older, online and first: Recommendations for retention and success. Australasian Journal of Educational Technology, 35(1), 57-69.

https://doi.org/10.14742/ajet.3913 